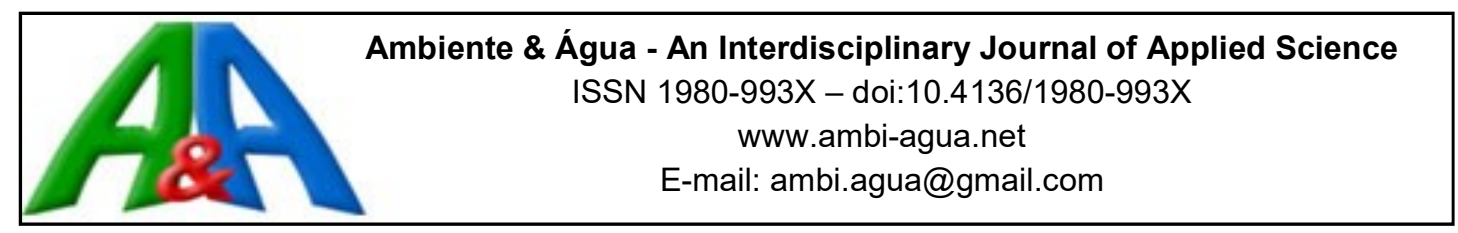

\title{
Anaerobic biodigestion of sugarcane vinasse under mesophilic conditions using manure as inoculum
}

\author{
doi:10.4136/ambi-agua.1897 \\ Received: 30 Mar. 2016; Accepted: 01 Aug. 2016

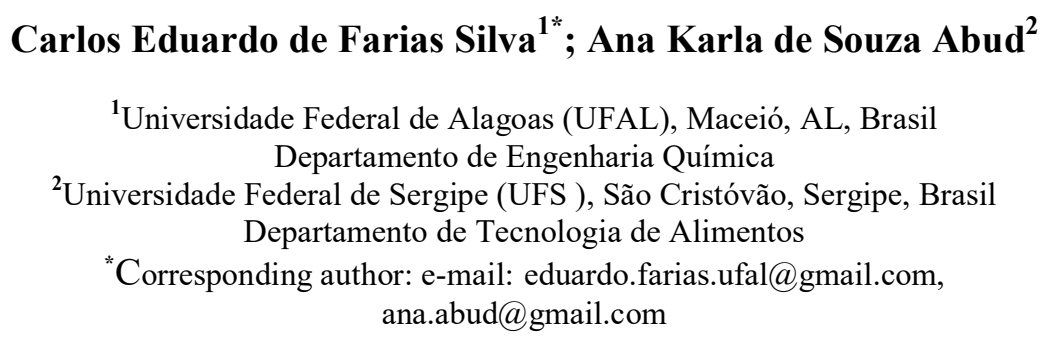

\begin{abstract}
Sugarcane vinasse is one of the most polluting residues produced by Brazilian ethanol industries, mainly because of its harmful effects on the environmental, such as high organic matter load and acidity. Anaerobic digestion is a highly efficient wastewater treatment method that could potentially be used to treat sugarcane vinasse. This study examined the anaerobic biodigestion of sugarcane vinasse in mesophilic conditions $\left(30-45^{\circ} \mathrm{C}\right)$ by varying the inoculum concentration ( 0.5 to $5.5 \%)$ and $\mathrm{pH}(6-8)$. Changes of Chemical Oxygen Demand (COD), total solids content, and yield and composition of biogas after the biodigestion of the vinasse were assessed. The vinasse was efficiently digested under mesophilic anaerobic conditions over a 23-day Hydraulic Retention Time (HRT) and a 5-day acidogenic phase with a consequent reduction of COD (54-83\%) and total solids (52-87\%). Statistical analyses at a confidence level of $95 \%$ suggested that temperature, $\mathrm{pH}$ and inoculum concentration did not influence on the anaerobic biodigestion of the vinasse. The optimal operating parameters were found to be temperatures of $30-35^{\circ} \mathrm{C}$, inoculum concentration of $0.5 \%$ and $\mathrm{pH}$ of $6-7$. The results emphasize the promising use of the treated sugarcane vinasse as a biofertilizer for agriculture, indicating that the anaerobic digestion process is an excellent alternative for Brazilian ethanol industries.
\end{abstract}

Keywords: anaerobic digestion, biomethane manure, inoculum concentration, vinasse.

\section{Biodigestão anaeróbica da vinhaça de cana-de-açúcar em condições mesófilas usando esterco como inóculo}

\section{RESUMO}

A vinhaça de cana-de-açúcar é um dos resíduos mais poluidores da indústria sucroalcooleira brasileira, principalmente pelas suas características nocivas ao meio ambiente, como o elevado teor de matéria orgânica e acidez. A digestão anaeróbia é um método altamente eficiente de tratamento de efluente e pode ser usada para tratar este resíduo. $\mathrm{O}$ estudo aborda a biodigestão anaeróbia de vinhaça de cana-de-açúcar em condições mesófilas $\left(30-45^{\circ} \mathrm{C}\right)$, variando a concentração de inóculo $(0,5$ a $5,5 \%)$ e o pH $(6-8)$. Foram 
verificados a remoção de DQO (Demanda Química de Oxigênio) e o teor de sólidos totais, além do rendimento e composição do biogás após a biodigestão da vinhaça. A vinhaça foi eficientemente digerida sob condições mesófilas em 23 dias de TRH (Tempo de Retenção Hidráulico) e 5 dias de fase acidogênica, com consequente redução de DQO (54 - 83\%) e de sólidos totais de $(52-87 \%)$. As análises estatísticas sugeriram que a temperatura, a concentração de inóculo e o pH não foram suficientes para caracterizar o processo de biodigestão anaeróbia da vinhaça, não apresentando diferença significativa entre os ensaios. Os parâmetros ótimos de operação foram definidos como temperatura entre 30 e $35^{\circ} \mathrm{C}$, concentraçao de inóculo de $0,5 \%$ e pH entre 6 e 7 . Os resultados evidenciam o uso promissor da vinhaça tratada como biofertilizante para a agricultura, indicando a digestão anaeróbia como um processo sustentável e ótima opção para as empresas sucroalcooleiras brasileiras.

Palavras-chave: biometano, concentração de inóculo, digestão anaeróbia, esterco, vinhaça.

\section{INTRODUCTION}

The growing public concern over the preservation of the environment has stimulated a worldwide search for more sustainable agricultural procedures and alternative sources of energy. Nevertheless, only a few countries have a plenitude of natural resources to produce large amounts of energy crops without jeopardizing their food production capacity. Brazil, for example, has developed a very modern sugarcane industry for ethanol production over the last 30 years. The country has a territory of 851 million hectares with climate conditions highly suitable to the production of massive amounts of sugarcane with minimal need for irrigation (Leite et al., 2009).

Sugarcane is cultivated in more than 100 countries around the world. However, $80 \%$ of sugarcane production is concentrated in 10 countries, among which Brazil is the leader in terms of cultivated area and ethanol industry scale (Doll and Foresti, 2010). The annual production of ethanol in Brazil is 28 million $\mathrm{m}^{3}$ (UDOP, 2014) which, when combined with the corn ethanol production of the United States, comprises about $70-80 \%$ of worldwide ethanol production (Vian, 2015).

Industrial processing of sugarcane results in the generation of large amounts of wastes such as bagasse, ashes, vinasse, and other liquid and gaseous residues (Doll and Foresti, 2010). The retrieval of energy and the production of diverse products, including the reuse of wastes, would be an application of the currently important concepts of biorefinery and sustainability for the Brazilian ethanol industry (Moraes et al., 2015).

Sugarcane vinasse, also named distillery water or stillage, is an aqueous byproduct resulting from ethanol distillation. The vinasse is commonly produced at a volume approximately $10-20$ times greater than the volume of ethanol. The vinasse usually exhibits high pollutant content mainly characterized by its low $\mathrm{pH}$, high corrosion ability, and large organic matter content (Kapajaru et al., 2010; Christopholetti et al., 2013; Silva and Abud, 2014; Moraes et al., 2015).

Anaerobic digestion has emerged as an alternative waste treatment method to the aerobic digestion processes mainly due to its higher organic matter degradation rate, little sludge formed, and production of energy through the synthesis of biogas, in addition to producing biofertilizers as an end product (Mohana et al., 2009). It has been widely used to treat municipal sludges and industrial effluents, this latter still with certain limitations (Chen et al., 2008). Anaerobic biodigestion is a process by which organic residues and effluents are biologically transformed in the absence of oxygen. It is a complex treatment approach that has a specific bioactive population divided into four different stages: hydrolysis, acidogenesis, acetogenesis, and metanogenesis (Lastella et al., 2002). This complexity has imparted a strong 
dependence of the anaerobic biodigestion on various factors, including temperature, $\mathrm{pH}$, organic matter loading, and the presence of hazardous substances (Rajendran et al., 2012; Lastella et al., 2002).

With respect to sugarcane vinasse, the use of anaerobic digestion as a treatment method has been rare due to the fact that the majority of the vinasse quantity has been used at an "in nature" state for the fertirrigation of sugarcane plantations. The vinasse has been directly applied to the soil because of its valuable phosphorus content, even though the long-term effects of this activity are still unclear, and the transportation costs are high (Christofoletti et al., 2013).

The application of anaerobic biodigestion technologies to treat sugarcane vinasse has not been shown to be advantageous because of the small gains involved in the use of biogas to generate electricity. It is now receiving more attention mainly due to environmental gains, but scientific progress on this topic is still unsatisfactory, with several questionable or conflicting studies (Moraes et al., 2015). An earlier report on the economic and energetic aspects of the anaerobic biodigestion of vinasse in sugarcane processing factories pointed out the considerable gains in terms of electricity or co-generation as well as alternative vehicle fuels. The energetic potential of vinasse, which has been lost by application of the "in nature" vinasse to soil, was comparable to the electrical demands of some cities, the generating capacity of some hydroelectric plants, and, in some cases, exceeded the energy obtained from combustion of the sugarcane bagasse. Therefore, the sustainability concepts involved in the anaerobic biodigestion of the vinasse must still be better explored in sugarcane biorefineries of Brazil (Moraes et al., 2014).

Due to the possibility of soil contamination and imbalance of physicochemical and microbiological characteristics, anaerobic digestion could potentially be used to treat the vinasse, mineralizing this byproduct while virtually maintaining its nitrogen, phosphorus and potassium (NPK) contents unchanged (Amon et al., 2006; 2007; Cruz et al., 2013). Even though the salt content, which is one of the main toxicity aspects of the continuous use of vinasse in fertirrigation, needs to be adjusted by dilution, it can generate considerable impact to the environment if handled improperly in addition to the fact that the management of salt concentrations is adjusted depending on the type of soil (Alves et al., 2015; Vadivel et al., 2014; Christofoletti et al., 2013).

Numerous approaches have been used to increase the efficiency of the anaerobic digestion process, especially the variation of operating conditions such as temperature, hydraulic retention time (HRT), $\mathrm{pH}$ and concentration of solids (Yadvika et al., 2004). Regarding temperature, the anaerobic biodigestion is generally classified into psychrophilic $\left(<30^{\circ} \mathrm{C}\right)$, mesophilic $\left(30-45^{\circ} \mathrm{C}\right)$ and thermophilic $\left(50-60^{\circ} \mathrm{C}\right)$ processes. Thermophilic anaerobic biodigestion has been considered to be more efficient for degradation of organic matter compared with the mesophilic processes (Yadvika et al., 2004), since a larger yield of biogas can be obtained. However, anaerobic processes involving effluents with high organic matter loading generate large amounts of acid compounds, which can hamper the methanogenesis stage, especially when the organic matter is comprised of simple (non-recalcitrant) substances, such as cellulose, hemicellulose and lignin (Doll and Foresti, 2010).

The present work examined the characteristics of biofertilizers and biogas obtained by anaerobic biodigestion of sugarcane vinasse under mesophilic conditions $\left(30-45^{\circ} \mathrm{C}\right)$. Operating parameters such as temperature, concentration of inoculum (bovine manure) and $\mathrm{pH}$ were studied by statistical methods in order to gain deeper insights into the biodigestion process and influence its development. 


\section{MATERIAL AND METHODS}

\subsection{Obtaining and characterization of sugarcane vinasse}

The sugarcane vinasse was kindly supplied by the Cachoeira biofuel plant and all experiments were conducted at the engineering chemistry laboratory of UFAL, both located in Maceió (AL), Brazil (latitude 9.40 S; longitude $35.43 \mathrm{~W}$ ). Freshly generated vinasse was collected and transported in cold vessels to the laboratory where it was stored in plastic bottles in a refrigerator for further analyses. The vinasse was characterized in terms of $\mathrm{pH}$, volatile and fixed total solids, chemical oxygen demand (COD), total nitrogen, ammoniacal nitrogen, chloride and phosphorus content, total acid content, and density, following the Standard Methods for Examination of Water and Wastewater (APHA, 1995).

The $\mathrm{pH}$ measurements were done with a potentiometer calibrated with $\mathrm{pH} 4.0$ and 7.0 buffer solutions. The total solid content was determined using a gravimetric method considering the difference of vinasse mass before and after drying at $105^{\circ} \mathrm{C}$. The total fixed solid content was determined after calcination at $550^{\circ} \mathrm{C}$ for $1 \mathrm{~h}$. The volatile solid (VS) content was calculated as a difference between the total solid content and the total fixed solid content. The COD analyses were performed by UV-Vis spectrophotometry by using potassium dichromate as an oxidizing agent under acidic condition and high temperature. The analytical curve used in the COD quantifications was obtained with potassium biphthalate solutions with various concentrations. The phosphorus content was determined using the ascorbic acid method by previously digesting the vinasse with concentrated acid. Potassium phosphate solutions with different concentrations were used to obtain the analytical curve. The chloride content was determined by the Mohr's method using standard $0.01 \mathrm{~N} \mathrm{AgNO}_{3}$ solution and $5 \%$ potassium chromate solution as an indicator, while the total acid content was determined by acid-base titration using standardized $0.1 \mathrm{~N} \mathrm{NaOH}$ solution and phenolphthalein indicator (1\%). The total and ammoniacal nitrogen contents were determined by the Kjeldahl method. All analyses were carried out in triplicate with exception of the COD determinations.

\subsection{Biodigestion trials}

The experiments of biodigestion were carried out using bovine manure as an inoculum. Plastic flasks ( $0.6 \mathrm{~L}$ working-volume and $0.2 \mathrm{~L}$ of headspace, according Angelidaki et al., 2009) with screw top lids were arranged with two openings at their top; the first one was used to drive the biogas to syringes, which served to store and quantify the gas through the displacement of the piston, and the second opening was used to collect aliquots daily as well as to adjust the $\mathrm{pH}$ with $40 \% \mathrm{NaOH}$ and $20 \% \mathrm{H}_{2} \mathrm{SO}_{4}$ solutions over the acidogenesis phase. The reactor heating was provided by a water bath Nova Técnica NT 235. The flasks were shaken manually once a day, just for sample collection.

The experiments were executed according to a full $2^{3}$ factorial design with three repetitions at the central point (Table 1). The variables temperature, inoculum concentration, and $\mathrm{pH}$ were studied with respect to their influence on the COD, biogas formation, and total phosphorus and nitrogen contents. The ending of biogas production (constant formed biogas volume) was used as a criterion to interrupt the biodigestion assays. Samples were collected daily in order to evaluate the variation of $\mathrm{pH}$ which was further adjusted to the value required for each experiment.

The inoculum concentration is important to the process and varies according to the material used for activating the microbial population (Raposo et al., 2012). In fact, the type of inoculum affects the microbial population in the process, as well as the difference in physico-chemical composition and biogas production capacity (De Vrieze et al., 2015). Manure has about $80 \mathrm{~g}$ manure VS/kg (Barros et al., 2009). In this study, the manure was 
used between $0.5-5.5 \%$ as inoculum, with load between $10-100 \mathrm{~g}$ vinasse $\mathrm{COD} / \mathrm{g}$ inoculum VS (50 as an average value) or $\mathrm{g}$ vinasse VS/g inoculum VS, based on De Vrieze et al. (2015) studies, to evaluate the interaction of various inoculum concentrations in the biogas and biofertilizer production.

Table 1. $2^{3}$ full factorial design conditions for anaerobic biodigestion of vinasse under mesophilic condition.

\begin{tabular}{cccc}
\hline Assay & $\begin{array}{c}\text { Inoculum } \\
\text { concentration }\end{array}$ & Temperature & $\mathrm{pH}$ \\
\hline 1 & $-1(0.5 \%)$ & $-1\left(30^{\circ} \mathrm{C}\right)$ & $-1(6.0)$ \\
2 & $1(5.5 \%)$ & $-1\left(30^{\circ} \mathrm{C}\right)$ & $-1(6.0)$ \\
3 & $-1(0.5 \%)$ & $-1\left(30^{\circ} \mathrm{C}\right)$ & $1(8.0)$ \\
4 & $1(5.5 \%)$ & $-1\left(30^{\circ} \mathrm{C}\right)$ & $1(8.0)$ \\
5 & $-1(0.5 \%)$ & $1\left(45^{\circ} \mathrm{C}\right)$ & $-1(6,0)$ \\
6 & $1(5.5 \%)$ & $1\left(45^{\circ} \mathrm{C}\right)$ & $-1(6.0)$ \\
7 & $-1(0.5 \%)$ & $1\left(45^{\circ} \mathrm{C}\right)$ & $1(8.0)$ \\
8 & $1(5.5 \%)$ & $1\left(45^{\circ} \mathrm{C}\right)$ & $1(8.0)$ \\
9 & $0(3.0 \%)$ & $0\left(37.5^{\circ} \mathrm{C}\right)$ & $0(7.0)$ \\
10 & $0(3.0 \%)$ & $0\left(37.5^{\circ} \mathrm{C}\right)$ & $0(7.0)$ \\
11 & $0(3.0 \%)$ & $0\left(37.5^{\circ} \mathrm{C}\right)$ & $0(7.0)$ \\
\hline
\end{tabular}

\subsection{Physical-chemical and microbiological characterization of the biofertilizers}

The solid products obtained in the biodigestion experiments were characterized by volatile solid content, total fixed solid content, COD, total nitrogen content, and total phosphorus content analyses, and a comparison of these parameters with those of the "in nature" vinasse was performed.

The analysis of coliforms was conducted by the most probable number (MPN) technique in three series of three tubes (United States, 2001). The presumptive test was done by inoculating the samples in Lauryl sulphate tryptose growth medium (LST, Acumedia ${ }^{\mathbb{B}}$ ) distributed into test tubes containing inverted fermentation Durham tubes. The samples were inoculated for 24 and $48 \mathrm{~h}$ at $35.5^{\circ} \mathrm{C}$. Afterwards, the test tubes showing a positive result (medium turbidity and gas formation) were used in confirmatory tests in which samples were inoculated and incubated in brilliant green bile broth $2 \%$ (VB, Merck ${ }^{\circledR}$ ) for 24 and $48 \mathrm{~h}$ at $35^{\circ} \mathrm{C}$, and in Escherichia coli agar (EC, Acumedia $\left.{ }^{\circledR}\right)$ for $24 \mathrm{~h}$ at $44.5^{\circ} \mathrm{C}$ to detect total coliforms and thermotolerant coliforms, respectively. All growth media were prepared according to the manufacturers' protocols.

\subsection{Concentration of carbonic gas and methane}

The quantification of $\mathrm{CO}_{2}$ was carried out using the biogas kit (alfakit) developed in collaboration with Embrapa Swine and Poultry. The analysis was done following the method of Orsat with some adaptations. The concentration of $\mathrm{CO}_{2}$ was determined by the precipitation of the gas with an alkaline solution. The concentration of $\mathrm{CH}_{4}$ was estimated by Equation 1.

$$
\% \mathrm{CH}_{4} \text { Theoretical }=100-\% \mathrm{CO}_{2}
$$

The concentrations of $\mathrm{CO}_{2}$ and $\mathrm{CH}_{4}$ were expressed as a percentage (\%) with an accuracy of $\pm 5 \%$ and were supposed to be relative parameters because only the existence of both gases was taken into account in the calculations. 


\subsection{Statistical Analyses}

Mean values of the data were compared using Tukey's test at confidence levels of $60 \%$, $95 \%$, and $99 \%$. All statistical calculi were done with the "Statistica" software, version 8.0.

\section{RESULTS AND DISCUSSION}

\subsection{Characterization of sugarcane vinasse and HRT of experiments}

The physicochemical characterization of the "in nature" sugarcane vinasse is reported in Table 2. It is seen that the vinasse exhibited parameters considered to be harmful to the environment, mainly the high COD, low $\mathrm{pH}$ and large total solid content (Salomon and Lora, 2009; Moraes et al., 2015). The hydraulic retention time (HRT) of the biodigestion assays was 25 days, but there was no significant production of biogas after 15 - 20 days. Accordingly, this time range was considered to represent an ideal HRT for anaerobic biodigestion of the vinasse.

Similar HRT values have been reported in the literature, but with regard to the biodigestion of other residues, for example vegetable waste (20 days) (Bouallagui et al., 2003), and semi-solid organic waste (22.5 - 33.7 days) (Lastella et al., 2002). This later study pointed out that the production of biogas over 33.7 days was larger but not significant, and that the use of longer HRTs considerably increases the costs of production. Amaral et al. (2004) reported that a HRT of 40 days reduced the total solid content of bovine manure that underwent anaerobic biodigestion, but that it decreased the relative production of biogas which was inferior to that obtained with a HRT of 20 days. Souza et al. (2008) observed the same effect after shortening the HRT of anaerobic biodigestion of swine waste from 30 to 10 days. Silva and Abud (2014) examined the batch anaerobic biodigestion of vinasse using bovine manure as an inoculum and a HRT of 70 days, and verified that there was no significant decrease of the COD of the effluent after 20 days of biodigestion.

Table 2. Physicochemical parameters of "in nature" sugarcane vinasse.

\begin{tabular}{|c|c|c|}
\hline \multirow{2}{*}{ Parameter } & \multicolumn{2}{|c|}{ Value } \\
\hline & This work $^{*}$ & Literature $^{* *}$ \\
\hline $\mathrm{pH}$ & 4.47 & $4.4-4.6$ \\
\hline Total solids (mg L ${ }^{-1}$ ) & $55728 \pm 3785$ & 52700 \\
\hline $\begin{array}{l}\text { Fixed total solids } \\
\left(\mathrm{mg} \mathrm{L}^{-1}\right)\end{array}$ & $16921 \pm 128$ & 12700 \\
\hline $\begin{array}{l}\text { Volatile total solids } \\
\left(\mathrm{mg} \mathrm{L}^{-1}\right)\end{array}$ & $38807 \pm 3657$ & 40000 \\
\hline $\mathrm{COD}\left(\mathrm{mg} \mathrm{O}_{2} \mathrm{~L}^{-1}\right)$ & 38911.2 & 45000 \\
\hline Chloride (mg Cl L ${ }^{-1}$ ) & $378.7 \pm 41$ & - \\
\hline $\begin{array}{l}\text { Phosphorus } \\
\left(\mathrm{mg} \mathrm{P} \mathrm{L}^{-1} \text { in } \mathrm{PO}_{4}^{3-}\right)\end{array}$ & $17.56 \pm 0.88$ & $\begin{array}{c}9-200 \\
\left(\mathrm{mg} \mathrm{P} . \mathrm{L}^{-1} \text { in } \mathrm{P}_{2} \mathrm{O}_{5}\right)\end{array}$ \\
\hline $\begin{array}{l}\text { Ammoniacal nitrogen } \\
\left(\mathrm{mg} \mathrm{N} \mathrm{L}^{-1} \text { in } \mathrm{NH}_{3}\right)\end{array}$ & $15.9 \pm 5.5$ & - \\
\hline Total nitrogen $\left(\mathrm{mg} \mathrm{N} \mathrm{L}^{-1}\right)$ & $711 \pm 153$ & $480-710$ \\
\hline Total acid (\%) & $6.54 \pm 0.33$ & - \\
\hline Density $\left(\mathrm{g} \mathrm{cm}^{-3}\right)$ & $1.015 \pm 0.005$ & - \\
\hline
\end{tabular}

*The data collection is represented by the mean \pm standard deviation.

** Salomon and Lora (2009). 
One of the features of batch processing is the evident division between the acidogenic and methanogenic phases because the acid substrates that will be consumed in the second phase to form biogas are synthetized in the acidogenic phase (Bouallagui et al., 2005). Figure 1 shows that the acidogenic phase started rapidly, with $\mathrm{pH}$ values decreasing to $4.5-5$ over the first 24 hours of biodigestion, and continued sharply for five days, which coincided with the beginning of the biogas production. The exponential phase started after 5 days of biodigestion (Figure 2).
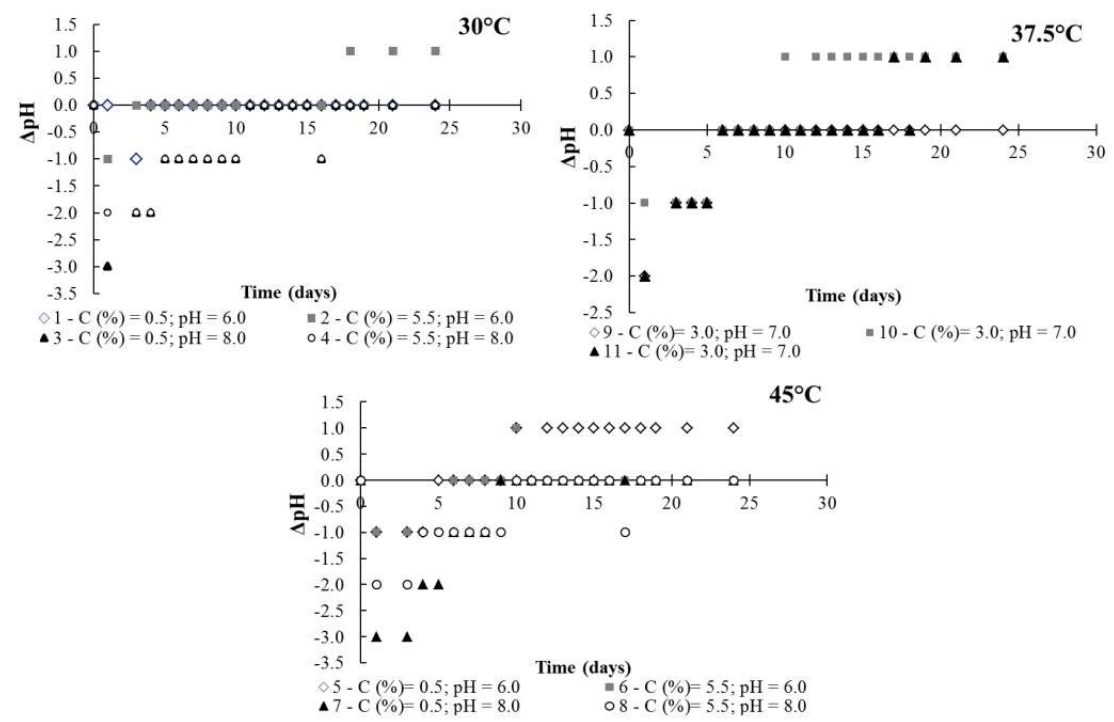

Figure 1. Evolution of $\mathrm{pH}$ upon biodigestion of sugarcane vinasse.

This rapid production of acid substances can be attributed to the fact that the sugarcane vinasse does not contain recalcitrant organic matter (cellulose, hemicellulose, lignin, or complex proteins) and undergoes elevated temperatures $\left(104-107^{\circ} \mathrm{C}\right)$ in the distillation process.

\subsection{Evolution of $\mathrm{pH}$ and biogas production}

It was observed in Figure 1 that the biodigestion assays conducted at the highest $\mathrm{pH}(8.0)$ displayed the longer times for stabilization of the $\mathrm{pH}$ most likely because the majority of the microbial population of the biodigester is better activated in an optimal $\mathrm{pH}$ range of 6.4 - 7.2. For $\mathrm{pH}$ values lower than 6.4 , the acid compounds synthesized by the acidogenic bacteria cannot be used by the methanogenic bacteria because these require a higher $\mathrm{pH}(7-8)$ to be totally activated. On the other hand, the biosynthesis of acids is inhibited under too high alkaline conditions, which could explain the longer acidogenic phase of the experiments conducted at $\mathrm{pH} 8.0$.

With respect to formation of biogas, the biodigestion of the vinasse at 30 and $37.5^{\circ} \mathrm{C}$ resulted in similar contents of biogas, whereas larger contents were observed for some assays performed at $45^{\circ} \mathrm{C}$ (Figure 2). The thermophilic biodigestion comprises advantageous high metabolic rates, but is a less stable process than mesophilic biodigestion and in addition requires heating (higher energy cost). The temperature effect on the thermophilic digestion is more significant in the hydrolysis step, especially when highly recalcitrant organic matter is used in the process (Bouallagui et al., 2004).

The content of $\mathrm{CO}_{2}$ ranged between $7.5 \%$ and $30 \%$, indicating a theoretical $\mathrm{CH}_{4}$ yield of $70-92.5 \%$ with decreasing levels of $\mathrm{CO}_{2}$ over the progress of the biodigestion. This reduction could be explained by the fact that $\mathrm{CO}_{2}$ is used as a substrate to the synthesis of 
$\mathrm{CH}_{4}$. Previous studies have reported an average yield of $\mathrm{CH}_{4}$ in anaerobic biodigestion processes of $55-70 \%$ (Rajendran et al., 2012; Amon et al., 2007; Bouallagui et al., 2004). Thus, the greater theoretical $\mathrm{CH}_{4}$ yield values found in this work can be attributed to other secondary gases (ammonia, hydrogen, hydrogen sulfide etc.).

The starting point of biogas production after the acidogenic phase is also related to the methanogenic microorganisms, which have slower growth than other types of microorganisms present in the biodigester. The growth time of methanogenic microorganisms varies between 5 and 16 days depending on the material undergoing biodigestion (Rajendran et al., 2012).

It was observed that at $45^{\circ} \mathrm{C}$ the largest inoculum concentrations resulted in the lowest yield of biogas, possibly due to the saturation of solid (microbial) loading $\left(6-11 \% \mathrm{~m} \mathrm{v}^{-1}\right)$ at high temperatures. The biodigestion of the vinasse occurred normally for temperatures between $30-37.5^{\circ} \mathrm{C}$ and solid loading between $6-11 \%$. Bouallagui et al. (2003) also reported an inhibition of the methanogenesis in the biodigestion of fruit and vegetable wastes with HRT of 12-20 days and solid loading of $10 \%$. Paper wastes were also anaerobically digested with bovine manure (approximately $2 \% \mathrm{~m} \mathrm{v}^{-1}$ ) at a solid loading of $4-12 \%$ and an average temperature of $26^{\circ} \mathrm{C}$, and the largest biogas yields were reached with the highest solid loadings (Yusuf and Nwaogazie, 2008). Kapajaru et al. (2010) studied the anaerobic digestion of wheat straw vinasse and recommended the feeding of the biodigester in a manner that the solid loading would be sustained at $50 \mathrm{~g} \mathrm{~L}^{-1}$. Nevertheless, the authors pointed out that the wheat vinasse had a COD of $150 \mathrm{~g} \mathrm{~L}^{-1}$ and a lignin content of approximately $75 \mathrm{~g} \mathrm{~L}^{-1}$.
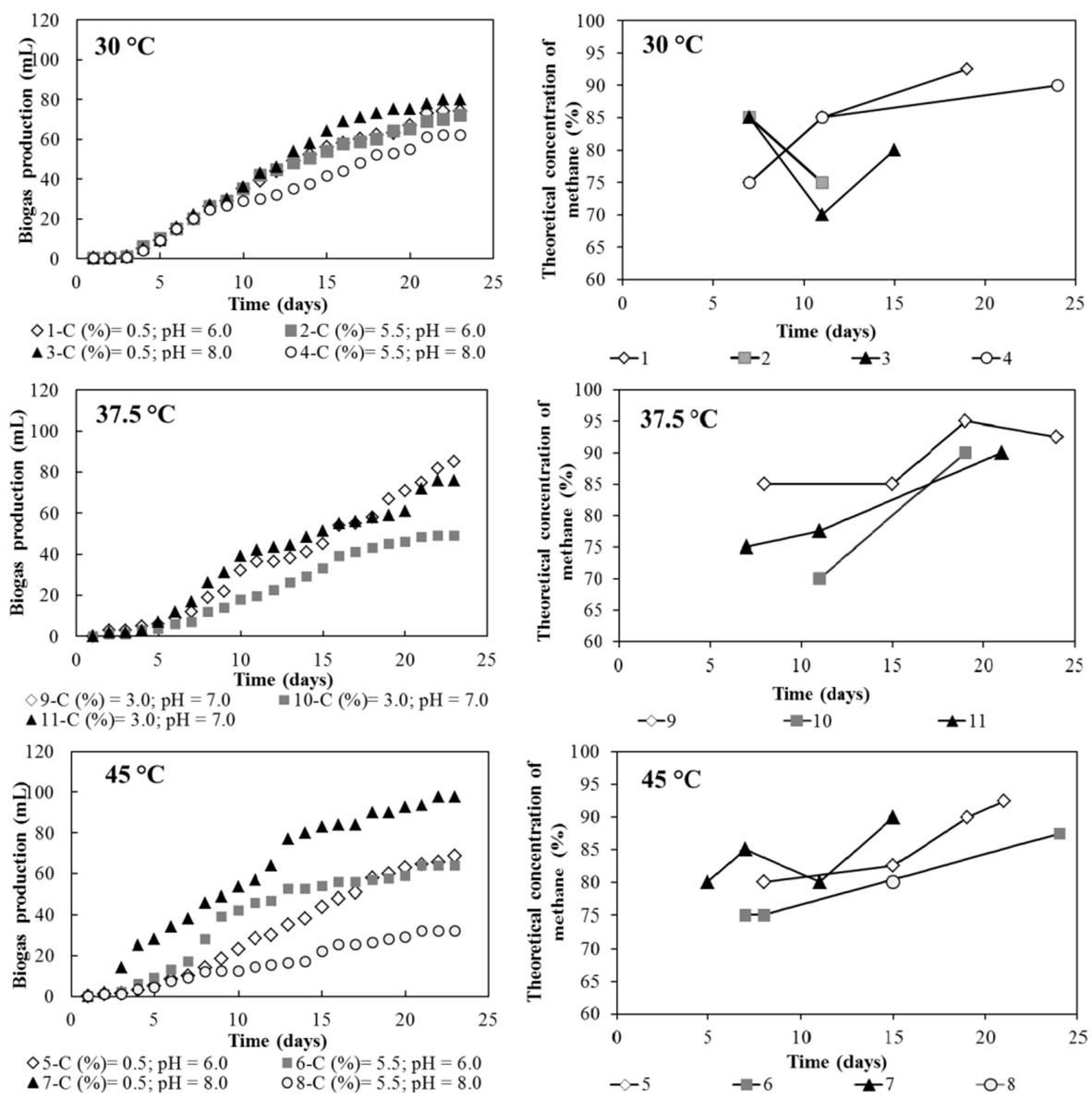

Figure 2. Monitoring of biogas formation and biogas quality. 


\subsection{Characterization of the biofertilizers}

Physicochemical and microbiological parameters of the biofertilizer samples obtained in accordance with the $2^{3}$ factorial design are shown in Table 3. For comparison purposes, the equivalent data of the "in nature" vinasse $\left(\mathrm{V}^{*}\right)$ were also included in Table 3. It is observed that the COD and total solid content of the biofertilizers decreased by $54-83 \%$ and $52-$ $87 \%$, respectively, in comparison with those of the vinasse. These decreased parameters have also been previously found in other studies which confirm the effectiveness of the biodigestion process in reducing organic loading of effluents (Lastella et al., 2002; Bouallagui et al., 2004, Amon et al., 2006; Silva and Abud, 2014). Statistically significant differences between the vinasse and the biofertilizers were also found with relation to the phosphorus content, total solids, fixed solids, and volatile solid contents $(\mathrm{p}<0.01)$. However, the total nitrogen content of the vinasse and the biofertilizers were not statistically different $(p>0.01)$. It is finally reported in Table 3 that the biofertilizers presented low concentrations of total and fecal coliforms.

Table 3. Microbiological and physicochemical parameters of the biofertilizers.

\begin{tabular}{|c|c|c|c|c|c|c|c|c|}
\hline \multirow{2}{*}{$\begin{array}{l}\text { 豞 } \\
\text { 岁 }\end{array}$} & \multirow{2}{*}{$\begin{array}{c}\mathrm{COD} \\
\left(\mathrm{mg} \mathrm{L}^{-1}\right)\end{array}$} & \multirow{2}{*}{$\begin{array}{c}\text { Total } \\
\text { solids } \\
\left(\mathrm{mg} \mathrm{L}^{-1}\right)\end{array}$} & \multirow{2}{*}{$\begin{array}{l}\text { Fixed total } \\
\text { solids } \\
\left(\mathrm{mg} \mathrm{L}^{-1}\right)\end{array}$} & \multirow{2}{*}{$\begin{array}{l}\text { Volatile total } \\
\text { solids } \\
\left(\mathrm{mg} \mathrm{L}^{-1}\right)\end{array}$} & \multirow{2}{*}{$\begin{array}{c}\text { Total } \\
\text { nitrogen } \\
\left(\mathrm{mg} \mathrm{N} \mathrm{L}^{-1}\right)\end{array}$} & \multirow{2}{*}{$\begin{array}{c}\text { Total } \\
\text { phosphorus } \\
\left(\mathrm{mg} \mathrm{P} \mathrm{L}^{-1}\right)\end{array}$} & \multicolumn{2}{|c|}{$\begin{array}{l}\text { Coliforms } \\
\text { NMP.mL } L^{-1} \text { ) }\end{array}$} \\
\hline & & & & & & & Total & Fecal \\
\hline 1 & 8628.66 & $27800 \pm 431^{\text {ef }}$ & $15770 \pm 85^{\mathrm{i}}$ & $12030 \pm 516^{\text {cde }}$ & $1010.91 \pm 186.2^{\mathrm{a}}$ & $19.55 \pm 2.30^{\mathrm{bcd}}$ & $1.1 .10^{3}$ & 30 \\
\hline 2 & 9536.94 & $30230 \pm 976^{\text {cde }}$ & $15980 \pm 311^{\mathrm{hi}}$ & $14250 \pm 665^{\mathrm{bcd}}$ & $813.70 \pm 195.7^{\mathrm{ab}}$ & $21.59 \pm 0.58^{\mathrm{b}}$ & $2.1 .10^{4}$ & 30 \\
\hline 3 & 11353.50 & $34900 \pm 283^{\mathrm{cd}}$ & $23465 \pm 530^{\mathrm{b}}$ & $11435 \pm 247^{\text {cde }}$ & $764.30 \pm 42.7^{\mathrm{ab}}$ & $12.63 \pm 1.24^{\mathrm{ef}}$ & $2.1 .10^{5}$ & 30 \\
\hline 4 & 14532.48 & $35290 \pm 410^{\text {cd }}$ & $22530 \pm 28^{\mathrm{bc}}$ & $12760 \pm 438^{\text {cde }}$ & $789.00 \pm 85.91^{\mathrm{ab}}$ & $17.92 \pm 0.00^{\text {bcde }}$ & 4.6.10 & 30 \\
\hline 5 & 8628.66 & $30635 \pm 78^{\text {cde }}$ & $21530 \pm 410^{\mathrm{cd}}$ & $9105 \pm 32^{\text {def }}$ & $789.00 \pm 85.91^{\mathrm{ab}}$ & $16.29 \pm 2.30^{\text {cdef }}$ & $2.3 .10^{4}$ & 4 \\
\hline 6 & 15894.90 & $44370 \pm 141^{\mathrm{b}}$ & $25900 \pm 156^{\mathrm{a}}$ & $18470 \pm 14^{\mathrm{b}}$ & $863.00 \pm 154.00^{\mathrm{ab}}$ & $57.84 \pm 1.15^{\mathrm{a}}$ & $3.0 .10^{2}$ & 30 \\
\hline 7 & 17711.46 & $35410 \pm 870^{\mathrm{c}}$ & $19850 \pm 803^{\text {de }}$ & $15560 \pm 7^{\mathrm{bc}}$ & $850.64 \pm 52.30^{\mathrm{ab}}$ & $14.66 \pm 1.15^{\text {def }}$ & $3.0 .10^{2}$ & 30 \\
\hline 8 & 14078.34 & $36035 \pm 35^{\mathrm{c}}$ & $21650 \pm 368^{\mathrm{cd}}$ & $14385 \pm 403^{\mathrm{bcd}}$ & $850.64 \pm 52.30^{\mathrm{ab}}$ & $13.85 \pm 1.15^{\mathrm{ef}}$ & $3.0 .10^{2}$ & 30 \\
\hline 9 & 14532.48 & $29245 \pm 92^{\text {def }}$ & $12270 \pm 99^{\mathrm{gh}}$ & $11975 \pm 7^{\text {cde }}$ & $789.00 \pm 85.40^{\mathrm{ab}}$ & $20.77 \pm 0.58^{\mathrm{bc}}$ & $3.0 .10^{2}$ & 30 \\
\hline 10 & 6357.96 & $23970 \pm 219^{f}$ & $19080 \pm 21^{\text {ef }}$ & $4890 \pm 198^{\mathrm{f}}$ & $665.72 \pm 73.97^{b}$ & $15.48 \pm 0.58^{\text {cdef }}$ & $3.6 .10^{4}$ & 40 \\
\hline 11 & 10899.36 & $25505 \pm 148^{\mathrm{ef}}$ & $17870 \pm 42^{\mathrm{fg}}$ & $7635 \pm 106^{\text {ef }}$ & $616.40 \pm 42.70^{\mathrm{b}}$ & $12.22 \pm 1.63^{\mathrm{f}}$ & $1.5 .10^{4}$ & 30 \\
\hline $\mathrm{V}^{*}$ & 38911.20 & $55728 \pm 3785^{\mathrm{a}}$ & $16921 \pm 128^{\mathrm{ghi}}$ & $38807 \pm 3656^{\mathrm{a}}$ & $721.79 \pm 154.9^{\mathrm{ab}}$ & $17.56 \pm 0.88^{\text {bcde }}$ & -- & -- \\
\hline
\end{tabular}

$\mathbf{V}^{*}=$ "in nature" vinasse. Means in the same column bearing the same letter are not significantly different from the vinasse parameters $(\mathrm{p}>0.01)$ according to the Tukey's test. All calculations were performed using the software ASSISTAT.

Importantly, the total nitrogen and phosphorus contents slightly increased with the gaseous dissimilation $(\mathrm{p}>0.01)$. This means that there was a reduction of organic matter of the vinasse without affecting its NPK content, which is the most important feature of the vinasse to be used in the fertirrigation of the sugarcane plantations. Therefore, the sustainable use of the biodigested vinasse as a biofertilizer could be advantageous for the Brazilian ethanol program, once generation both of biogas (energy gain) and biofertilizer (chemical gain) is involved in this approach.

\section{IPABH}

Rev. Ambient. Água vol. 11 n. 4 Taubaté - Oct. / Dec. 2016 
In addition to the phosphorus and nitrogen content (which remained virtually unchanged), it is important to mention the potassium content and assume that the content remained stable. According to Salomon and Lora (2009), the potassium content is around $1400 \mathrm{mg} \mathrm{L}^{-1}\left(\mathrm{~K}_{2} \mathrm{O}\right)$ and can be used in sugarcane cultivation since the sugarcane plant belongs in the group of high potassium-demanding plants (Clements, 1980).

Only a few studies on the use of sugarcane vinasse as a biofertilizer in cultivated areas have been conducted in order to confirm its efficiency in agricultural productivity. Even though application studies of the vinasse have been performed through the last decades, it is worth mentioning that the use of "in nature" vinasse in fertirrigation is still controlled by Brazilian environmental agencies due to the risks mainly resulting from its high organic and salt loadings (Salomon and Lora, 2009). The present work demonstrates that these drawbacks of sugarcane vinasse could be mitigated by using the anaerobic biodigestion process to stabilize this effluent.

Regarding biodigestion temperature, it was found that the biogas yield and the parameters of the biofertilizers did not significantly change over the range $30-37.5^{\circ} \mathrm{C}$. These findings were considered useful because they indicate absence of heating during biodigestion of the vinasse. In tropical regions of Brazil, such as the Brazilian northeast, the sugarcane harvest periods and ethanol production involve these average values of daily temperature. Generally speaking, the operating temperature range for anaerobic digestion is in close association with the bioclimatic conditions, since heating relatively increases the costs of a production plant (Bouallagui et al., 2004).

\subsection{Statistical analysis of $2^{3}$ factorial design biodigestion assays}

Statistical analysis of the results obtained according to the $2^{3}$ factorial design allowed for the evaluation of the influence of temperature, inoculum concentration and $\mathrm{pH}$ on the main physicochemical parameters and microbiological characteristics of the biofertilizers as well as the yield of biogas. Taking into account the range of temperature $\left(30-45^{\circ} \mathrm{C}\right)$, inoculum concentration $\left(0.5-5.5 \% \mathrm{~m} \mathrm{v}^{-1}\right)$, and $\mathrm{pH}(6-8)$, none of the variables and their interactions was statistically significant $(\mathrm{p}>0.05)$ as shown in Figure 3. This result can be considered positive because it reveals an operating range that does not significantly change the biodigestion process of the vinasse.

Although it is difficult to reach the temperature of $45^{\circ} \mathrm{C}$ without using a heating system, the use of a smaller amount of inoculum may be helpful to digest a greater volume of vinasse, but there is also the possibility of using both simultaneously in order to treat the surplus of manure. Despite the fact that the temperature and inoculum concentration did not significantly influence the biodigestion, they presented positive and negative influences on the process. Using a confidence level of $60 \%$, a statistical significance was observed for nearly all variables and their interactions. It is difficult to provide a complete explanation for this result; however, it is assumed in this study that temperature, inoculum concentration and $\mathrm{pH}$ are not sufficient variables to model the anaerobic biodigestion of the sugarcane vinasse.

Thus, an operating temperature between $30-35^{\circ} \mathrm{C}$ is suggested, as well as an inoculum (manure) concentration of $0.5 \%$ and a $\mathrm{pH}$ between $6-7$, as the best conditions for treatment of the organic matter, biogas production and process stability for the anaerobic biodigestion of the sugarcane vinasse. Considering that Brazil produces approximately 28 million $\mathrm{m}^{3}$ of ethanol, which results in the generation of 280 million $\mathrm{m}^{3}$ of sugarcane vinasse, the anaerobically biodigested vinasse would represent a sustainable gain for the Brazilian ethanol program, not only in terms of energy, by the production of biogas, but also in environmental terms due to the production of biofertilizers with diminished organic matter loading. 

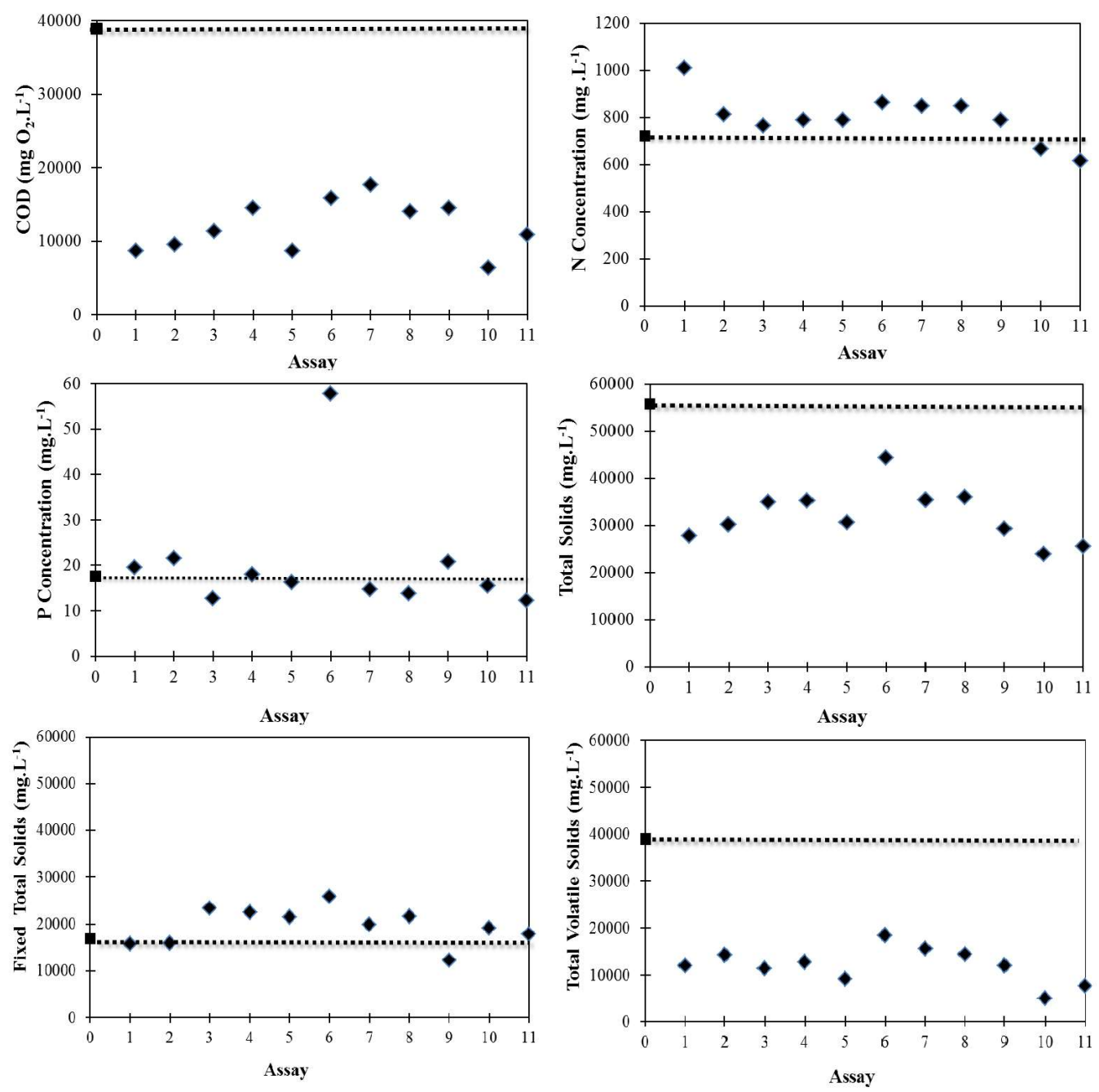

Figure 3. Physicochemical parameters of biofertilizers ( $\downarrow)$ obtained by anaerobic biodigestion of "in nature" sugarcane vinasse ( $\mathbf{\square})$.

The biogas produced from the anaerobic biodigestion of the vinasse could be used in the ethanol production plant to generate heat and electricity for the stages of distillation and evaporation or to the maintain the biodigester (in the case of opting to heat the biodigester throughout the process) (Kaparaju et al., 2010).

\section{CONCLUSIONS}

The sugarcane vinasse was successfully biodigested under anaerobic conditions with a reduction of COD and total solid contents of $54-83 \%$ and $52-87 \%$, respectively, with an HRT of 23 days and an acidogenic phase of 5 days. The biogas yield in most assays was similar, as well as the physical-chemical parameters of the biofertilizer. This was confirmed by statistical analysis, where the variables of temperature $\left(30-45^{\circ} \mathrm{C}\right)$, inoculum concentration $(0.5-5.5 \%)$ and $\mathrm{pH}(6-8)$ did not differ statistically at a confidence level of $95 \%$. The best operating conditions for biodigestion of the vinasse were found to be: temperature of $30-35^{\circ} \mathrm{C}$, inoculum concentration of $0.5 \%$ and $\mathrm{pH}$ of $6-7$. The total nitrogen and phosphorus contents of the vinasse remained the same or slightly increased after the biodigestion process, whereas the organic matter loading was substantially removed. These findings emphasize the 
promising use of the biodigested sugarcane vinasse as a biofertilizer for agricultural applications, turning the anaerobic digestion of this residue into a sustainable gain for the Brazilian ethanol program.

\section{ACKNOWLEDGEMENTS}

The authors thank the Cachoeira ethanol plant for kindly supplying the sugarcane vinasse used in this work, the FAPEAL for the fellowship granted and the laboratory of environmental systems (LSA) for the analysis facilities.

\section{REFERENCES}

ALVES, P. R. L.; NATAL-DA-LUZ, T.; SOUSA, J. P.; CARDOSO, E. J. B. N. Ecotoxicological characterization of sugarcane vinasses when applied to tropical soils. Science of the Total Environment, v. 526, p. 222-232, 2015. http://dx. doi.org/10.1016/j.scitotenv.2015.03.150

AMARAL, C. M. C.; AMARAL, L. A.; LUCAS JUNIOR; NASCIMENTO, A. A.; FERREIRA, D. S.; MACHADO, M. R. F. Biodigestao anaeróbica de dejetos de bovinos leiteiros submetidos a diferentes tempos de retenção hidráulica. Ciencia Rural, v. 34, n. 6, p. 1897-1902, 2004.

AMON, T.; AMON, B.; KRYVORUCHKO, V.; BODIROZA, V.; POTSCH, E.; ZOLLITSCH, W. Optimising methane yield from anaerobic digestion of manure: Effects of dairy systems and of glycerine supplementation. International Congress Series, v. 1293, p. 217-220, 2006. http://dx.doi.org/10.1016/j.ics.2006.03.007

AMON, T.; AMON, B.; KRYVORUCHKO, V.; ZOLLITSCH, W.; MAYER, W.; GRUBER, L. Biogàs production from maize and dairy cattle manure - Influence of biomass composition on the methane yield. Agriculture Ecosystems \& Environment, v. 118, p. 173-182, 2007. http://dx.doi.org/10.1016/j.agee.2006.05.007

ANGELIDAKI, I.; ALVES, M.; BORZACCONI, L.; CAMPO, J. L.; GUVY, A. J. et al. Defining the biomethane potential (BMP) of solid organic wastes and energy crops: a proposed protocol for batch assays. Water Science and Technology, v. 59, p. 927-934, 2009. http://dx.doi.org/10.2166/wst.2009.040

AMERICAN PUBLIC HEALTH ASSOCIATION - APHA. Standard METHODS FOR THE EXAMINATION OF WATER AND WASTEWATER. 19th Edition. Washington, D.C, 1995.

BARROS, R. M.; TIAGO FILHO, G. L.; NASCIMENTO, Y. D. S.; GUSHIKEN, E.; CALHEIROS, H. C.; SILVA, F. G. B. et al. Estudo da produçao de biogas da digestao anaerobica de esterco bovino em um biodigestor. Revista Brasileira de Energia, v. 15, n. 2, p. 95-116, 2009.

BOUALlOGUI, H.; BEN CHEIKH, R.; MAROUANI, L.; HANDI, M. Mesophilic biogás production from fruit and vegetable waste in a tubular digester. Bioresource Technology, v. 86, p. 85-89, 2003. http://dx.doi.org/10.1016/S0960-8524(02)00097-4 
BOUALlOGUI, H.; TORRIJOS, M.; GADOR, J. J.; MOLETTA, R.; BEN CHEIKH, R.; TOUHAMI, Y. et al. Two-phases anaerobic digestion of fruit and vegetable wastes: bioreactors performance. Biochemical Engineering Journal, v. 21, p. 193-197, 2004. http://dx.doi.org/10.1016/j.bej.2004.05.001

BOUALlOGUI, H.; TOUHAMI, Y.; BEN CHEIKH, R.; HANDI, M. Bioreactor performance in anaerobic digestion of fruit and vegetable wastes. Process Biochemistry, v. 40, p. 989-995, 2005. http://dx.doi.org/10.1016/j.procbio.2004.03.007

CHEN, Y.; CHENG, J. J.; CREAMER, K. S. Inhibition of anaerobic digestion process: A review. Bioresource Technology, v. 99, p. 4044-4064, 2008. http://dx.doi.org/ 10.1016/j.biortech.2007.01.057

CHRISTOFOLETTI, C. A.; ESCHER, J. P.; CORREIA, J. E.; MARINHO, J. F. V.; FONTANETTI, C. S. Sugarcane vinasse environmental implications of its use. Waste Management, v. 33, p. 2752-2761, 2013. http://dx.doi.org/10.1016/j.wasman .2013.09.005

CLEMENTS, H. F. Sugarcane crop lagging and crop control: principles and practices. Honolulu: University press of Hawaii, 1980. 520p.

CRUZ, L. F. L. S.; DUARTE, C. G.; MALHEIROS, T. F.; PIRES, E. Analise da viabilidade técnica, econômica e ambiental das atuais formas de aproveitamento da vinhaça: fertirrigaçao, concentração e biodigestao. Revista Brasileira de Ciências Ambientais, v. 29, p. 111-127, 2013.

DE VRIEZE, J.; RAPORT, L.; WILLEMS, B.; VERBRUGGE, S.; VOLCKE, E.; MEERS, E. et al. Inoculum selection influences the biochemical methane potential of agro-industrial substrates. Microbiol Biotechnology, v. 8, p. 776-786, 2015. http://dx.doi.org/ $10.1111 / 1751-7915.12268$

DOLL, M. M. R.; FORESTI, E. Efeito do bicarbonato de sódio no tratamento de vinhaça em AnSBBR operado a 55 e $35^{\circ}$ C. Engenharia Sanitaria e Ambiental, v. 15, n. 3, p. $273-$ 282, 2010. http://dx.doi.org/10.1590/S1413-41522010000300011

KAPAJARU, P.; SERRANO, M.; ANGELIDAKI, I. Optimization of biogas production from wheat straw stillage in UASB reactor. Applied Energy, v. 87, p. 3779-3783, 2010. http://dx.doi.org/10.1016/j.apenergy.2010.06.005

LASTELlA, G.; TESTA, C.; CORNACCHIA, G.; NOTORNICOLA, M.; VOLTASIO, F.; SHARMA, V. K. Anaerobic digestion of semi-solid organic waste: biogás production and its purification. Energy Conversion and Management, v. 43, p. 63-75, 2002. http://dx.doi.org/10.1016/S0196-8904(01)00011-5

LEITE, R. C. C.; LEAL, M. R. L.V.; CORTEZ, L. A. B.; GRIFFIN, W. M.; SCANDIFFIO, M. I. G. Can Brazil replace 5\% of the 2025 gasoline world demand with ethanol? Energy, v. 34, n. 5, p. 655-651, 2009. http://dx.doi.org/10.1016/j.energy.2008.11.001

MOHANA, S.; ACHARYA, B. K.; MADAMWAR, D. Distillery spent wash: treatment technologies and potentials applications. Journal of Hazardous Materials, v. 163, p. 12-25, 2009. http://dx.doi.org/10.1016/j.jhazmat.2008.06.079 
MORAES, B. S.; JUNQUEIRA, T. L.; PAVANELlO, L. G.; CAVALETT, O.; MANTELATTO, P. E.; BONOMI, A. et al. Anaerobic digestion of vinasse from sugarcane biorefineries in Brazil from energy, environmental, and economic perspectives: profit or expense? Applied Energy, v. 113, p. 825-835, 2014. http://dx.doi.org/10.1016/j.apenergy.2013.07.018

MORAES, B. S.; ZAIAT, M.; BONOMI, A. Anaerobic digestion of vinasse from sugarcane ethanol production in Brazil: challenges and perspectives. Renewable and Sustainable Energy Reviews, v. 44, p. 888-903, 2015. http://dx.doi.org/10.1016/j.rser.2015.01.023

RAJENDRAN, K.; ASLANZADEH, S.; TAHERZADEH, M. J. Household biogás digesters A Review. Energies, v. 5, p. 2911-2942, 2012. http://dx.doi.org/10.3390/en5082911

RAPOSO, F.; DE LA RUBIA, M. A.; FERNANDEZ-CEGRI, V.; BORJA R. Anaerobic digestion of solid organic substrates in batch mode: an overview relating to methane yields and experimental procedures. Renewable and Sustainable Energy Reviews, v. 16, n. 1, p. 861-877, 2012. http://dx.doi.org/10.1016/j.rser.2011.09.008

SALOMON, K. R.; LORA, E. E. S. Estimate of the electric energy generating potential of different sources of biogas in Brazil. Biomass \& Bioenergy, v. 33, p. 1101-1107, 2009. http://dx.doi.org/10.1016/j.biombioe.2009.03.001

SILVA, C. E. F.; ABUD, A. K. S. Acompanhamento do tempo de retenção hidráulico (TRH) na biodigestao da vinhaça e utilização de seu biofertilizante em sementes de feijão. Scientia Plena, v. 10, n. 7, p. 1-7, 2014.

SOUZA, C. F.; CAMPOS, J. A.; SANTOS, C. R.; BRESSAN, W. S., MOGAMI, C. A. Produçao volumétrica de metano - dejetos de suínos. Ciência e Agrotecnologia, v. 32, n. 1, p. 219-224, 2008. http://dx.doi.org/10.1590/S1413-70542008000100032

UNIÃO DOS PRODUTORES DE BIOENERGIA - UDOP. Acompanhamento da produção sucroalcoleira: SAFRA 2012/2013. 2014. Available in: http:/www.udop.com.br/index. php? item=safras. Access in: 2015.

UNITED STATES. Department of Health and Human Services. BAM - Bacteriological Analytical Manual. 2001. Available in: http:/www.fda.gov/Food/FoodScience Research/LaboratoryMethods/ucm2006949.htm. Access in: 2015.

VADIVEL, R.; MINHAS, P. S.; SURRESH, K. P.; SINGH, Y.; NAGESHWAR RAO D. V. K.; NIRMALE, A. Significance of vinasses waste management in agriculture and environmental quality - Review. African Journal of Agricultural Research, v. 9, n. 38, p. 2862-2873, 2014. http://dx.doi.org/10.5897/AJAR2014.8819

VIAN, C. E. F. EMBRAPA: Mercado da cana-de-açúcar. 2015. Available in: http://www.agencia.cnptia.embrapa.br/gestor/cana-de-cucar/arvore/CONTAG01_68_71 1200516719.html. Access in: 2015.

YUSUF, M. O. L.; NWAOGAZIE, L. I. Effect of waste paper on biogás production from codigestion of cow dung and water hyacinth in batch reactors. Journal of Applied Sciences and Environmental Management, v. 12, n. 4, p. 95-98, 2008. http://dx.doi.org/10.4314/jasem.v12i4.55245 
YADVIKA; SANTOSH; SREEKRISHNAN, T. R.; KOHLI, S.; RANA, V. Enhancement of biogás production from solid substrates using different techniques - a review. Bioresource Technology, v. 95, p. 1-10, 2004. http://dx.doi.org/10.1016/j. biortech.2004.02.010 